\title{
Mele Lāhui: The Importance Of Pono In Hawaiian Poetry
}

\begin{abstract}
Mele $^{1}$, which are poetry, music, chants, and songs, have been a foundational part of the histories and lives of the Kānaka Maoli of Hawai'i. We have used mele to record and recount our histories and stories, as well as our ideas about the lives of our people and our land. Mele have been a vital part of our cultural belief systems and practices, our connection to our 'āina, our land base, as well as our formal religious practices and our informal daily practices. Mele have also been vital to our political theories, ideas, and practices.

There are many different genres of Hawaiian mele, including mele ko'ihonua, which are cosmogonic genealogies; mele wahi pana, mele written in honour of historically and culturally-significant places; mele inoa, mele written in honour of a person and their name; as there are mele aloha, which are mele written to express great love and affection. The focus of this paper is mele lāhui, or mele written in honour of the lāhui, the Hawaiian people and nation. In a way, each of the other forms of mele could be seen as mele lāhui, as they are mele written by and for the lāhui, the Hawaiian people. The term mele lāhui, however, does not actually appear until relatively recently in Hawaiian history, during the reign of Kamehameha V, Lot Kapuāiwa (1863-1872), at a time in which Hawai'i's engagements and interactions with the colonial peoples and nations of the US and Europe made it necessary to distinguish ourselves as a lāhui. Lydia Kamaka'eha Lili'u, to be known as Queen Lili'uokalani in later years, was asked by the King to write a national anthem, which she called, 'He Mele Lahui Hawaii'. It was not, however, until the overthrow of the Hawaiian Kingdom in 1893 that we see a predominance of mele lāhui being composed and published. Between the overthrow in 1893 and annexation to the US in 1898, over 300
\end{abstract}

Dr. Leilani Basham traces her genealogy to the people of the islands of O'ahu and Kaua'i. She is an Assistant Professor of Contemporary Hawaiian Studies, teaching both Hawaiian Language and Hawaiian Studies courses at the University of Hawai'i-West O‘ahu. 
mele lāhui were published in Hawaiian language newspapers and books. These mele were composed to show resistance to foreign and American colonialism and as assertions of Hawaiian rights to sovereignty and independence. These mele lāhui also contain information which relate historical details of the events. They honour the heroes of these events and the places where they occurred. They also criticise and disparage the enemies of the people. The mele are reflective of cultural, religious, and political values and practices.

In addition, these mele are filled with various conceptualisations of the lāhui (the nation, people), ea (life, breath, sovereignty, independence), as well as their connection to 'aina (land) and that which is pono (proper, righteous, and balanced). These are representative of Hawaiian ideas and ideals, and traditional perceptions and conceptions of our world, our nation, and our people. In this paper I focus on the concept of pono, specifically analysing its meanings and uses, both historically and politically, followed by discussion of the meaning and value of pono as it is used within mele lāhui.

A hua a pane; a pane ka waha; he ho'olono ko 'one'i.

'A word in reply; open the mouth and speak, for a listener is here'. ${ }^{2}$

This 'ôlelo no'eau ${ }^{3}$ is used as a challenge in riddling competitions. The riddle, for me, is how do we, as a people, create a nation and achieve some form of self-determination in this modern era. I believe that any nation we create must be founded, not on Western conceptualisations of nations and sovereignty, but on traditional conceptualisations of our 'āina and our lāhui. In order to better understand these foundations and conceptualisations, I will take the advice of the 'olelo no'eau and 'ho'olono' or listen to the answers provided by the words of our ancestors.

\section{He aha ka mea e pono ai?}

Let's start with an examination of the word 'pono'. As always, there is not a direct match between Hawaiian and English words. The word pono is usually translated in English as 'righteous' or 'proper,' but is, in reality, much deeper, broader, and more complex, as evidenced by its definition in the two most complete Hawaiian language dictionaries. In Pukui and Elbert's 1986 dictionary, pono occupies nearly three-quarters of a column, while in Lorrin Andrews' 1865 
dictionary it occupies over half of a column. In the longer version of this paper I reproduce the entries in their entirety, but here will excerpt enough to demonstrate the multiplicity of meanings. The reader should bear in mind that, although enumerated in the style of dictionaries, as if they are separate, different meanings, in actuality, each of the meanings are interconnected and overlapping. Here is the excerpt from the Pukui and Elbert dictionary:

pono. 1. nvs. Goodness, uprightness, morality, moral qualities, correct or proper procedure, excellence, well-being, prosperity, welfare, benefit, behalf, equity, sake, true condition or nature, duty; moral, fitting, proper, righteous, right, upright, just, virtuous, fair, beneficial, successful, in perfect order, accurate, correct, eased, relieved; should, ought, must, necessary, Pono 'ole, unjust, unrighteous, dishonest, unprincipled, unfair, wrong. No kou pono, in your behalf. $\mathrm{Ka}$ pono o ka lehulehu, public welfare. Nā pono lāhui kānaka, human rights. Nā pono o nā wāhine, women's rights. Ka pono kahiko, the old morality or moral system. Pono i ke kānāwai, legal, legality. Pono 'ole ka mana'o, disturbed, worried, upset... Kōkua no ka pono o ka lehulehu, help for the public welfare. Ka no'ono'o e pono ai kèia hana, the study necessary for this work... Ke ui mai nei 'oe, 'a'ohe a'u pono, when you turn to me, I have no rights. ... Aia ka pono, 'o ka pae aku, what is necessary is to reach shore. Pono e pili pa'a loa, inalienable rights. Ho'o.pono. Righteous, respectable, correct, upright; to behave correctly. Ho'opono 'ole, unjust, dishonest. 2. vs. Completely, properly, rightly, well, exactly, carefully, satisfactorily, much (an intensifier). Pau pono, completely finished. Piha pono, completely filled; complete, as a thought; clear... 3. n. Property, resources, assets, fortune, belongings, equipment, household goods, furniture, gear of any kind, possessions, accessories, necessities. 4. n. Use, purpose, plan. $E$ ku'u haku, pale ka pono! 'A'ohe pono $i$ koe, ho'okahi nō pono 'o ka ho'i wale nō koe o kākou, kauka'i aku nei ho'i ka pono i kō kaikuahine muli la ho'i... (Laie 419; priest is advising his lord to give up quest of Lā'ie and depend on his sister's help), my lord, set aside the plan; there is no hope left; the only hope is for us to go back and depend on your youngest sister... 5. Hope. See ex., pono 4. Ua pau ka pono a ke kauka, the doctor has lost hope. 6. vs. Careless, informal, improper, any kind of (preceding a stem). Pono 'ai, to eat in any way or anything, take potluck. Pono hana, to work any way that suits one... ${ }^{4}$

Andrews defines pono as follows: 
Po-NO, $v$. To be good; to be right; to be just; to be morally upright.

2. To be good; to bless; to be for the comfort or convenience of one.

3. To be well, i. e., in bodily health.

4. Hoo. To justify one suspected of wrong; to clear or acquit, as an accused person. See APONO.

5. To avenge an injured person.

6. To ordain; to appoint.

7. To use, as money; to trade. Note.-Pono is frequently used impersonally and also as a helping verb before an infinitive, and signifies, it is right; it is proper; it ought; it may; it is worthy, \&c. The form e pono ai or $i$ pono ai is used very frequently; the word expressing the thing causing the favor or good or benefit, going before. O ka naauao ka mea $e$ pono ai ke aupuni, knowledge is the thing to bless a kingdom.

PO-NO, s. Goodness; uprightness; moral good; rectitude of conduct.

2. That which is right or excellent; abstract, righteousness; excellency.

3. Duty; obligation; authority. Mark 11:28, 29, 33.

Po-NO, adj. Good; right; lawful; acceptable; beautiful; nani.

2. Possible; able; proper; fit; wa pono, a proper time.

Po-NO, $a d v$. Is used in various senses.

1. As qualifying verbs, and signifies, well; rightly; truly; properly, \&c.

2. It is used as an intensive of the preceding verb; as, haka pono, to look at earnestly; ku pono, to stand opposite to. ${ }^{5}$

When we look at the word pono in the descriptions and the mele lāhui below, we must retain these multiple understandings of the word. In order to encourage and assist the reader, I will not choose a translation for pono but will leave it in Hawaiian.

Ua mau ke ea o ka 'āina i ka pono: The historical and political meaning of pono

Traditionally, according to Samuel Kamakau, Hawaiians had laws which governed behaviour and which pre-date contact with the West. These were called kānāwai and Kamakau describes them as follows: 
O ke kanawai i kalana ola. O kela ame ka make, o ka pono ame ka hewa. O keia mau kanawai elua, o ia na kanawai i malama ia e ka Moi a i hoomalu ia ma luna o ke aupuni. ${ }^{6}$

There is a law that grants life. That along with death, pono and hewa (wrongdoing, the opposite of pono). These two laws, they are the laws which were maintained by the Mō'i 1 and which were protected in the government. ${ }^{7}$

In this description, Kamakau describes one kānāwai as 'Kalanaola' ('Give or Grant Life') and 'make' ('death'). I believe this refers to the power of the $\mathrm{Mō}^{\prime} \overline{1}$ (king, queen, sovereign ruler) to protect the life as well as take the life of his people. However, the second law, 'pono' and 'hewa' ('wrong' or 'unpono behaviour') requires that this power to give and take life be exercised with great care. Indeed, it was a decision that had to be based on that which was pono. These kānāwai neither prohibit nor require specific behaviours or actions. Rather, they affirm that which is a foundational belief and intrinsic part of the system of values. This foundation of pono must be considered and achieved in all transactions between people, as well their interactions with the spiritual world and their environment.

As such, pono was essential to the rule of any Mō'î. John Charlot described the role of pono in the reign of the Mō's. He states:

Pono is a key word in Hawaiian politico-religious literature and has been defined very widely from moral righteousness to a correctness in practical terms that leads to success. In Hawaiian thinking, pono seems to incorporate both aspects: the right person must act rightly for the proper effect. ${ }^{8}$

Charlot described the importance of pono in the reign of Kamehameha Pai'ea, quoting several lines from the mele, 'Haui $\mathrm{Ka}$ Lani', in which Kamehameha is described as, 'He ali'i pono, he ali'i pono, he honua pono' ('A righteous chief, a righteous chief, a righteous earth'), which shows the interdependence of these two things - the chief and the earth. ${ }^{9}$ A later line in the mele states, 'I hanau a pono ia mai ka mehameha' ('the lonely one, Kamehameha, is born and is righteous'). Charlot connected these lines in the mele to Kamehameha's final words, quoted by Charlot as, ' $\mathrm{E}$ 'oni wale nō 'oukou i ku'u pono a ...' ('Move towards my rightness'), meaning that his 
traditions should continue in the righteous manner in which he had established them. ${ }^{10}$

Noenoe Silva also described the importance of pono in the reign of any $\mathrm{Mo}^{\overline{1}} \overline{1}$, stating that, 'in the ancient Kanaka world, pono meant that the akua (deities), ali'i, kahuna, maka'āinana, and 'āina (land) lived in balance with each other, and that people had enough to eat and were healthy'. ${ }^{11}$

Lilikalā Kame'eleihiwa tracked the transformation of pono over time, as affected by the continued increase of Western influence in business, government, and religion, as well as the traumatic effects caused by the death of huge portions of the population due to various epidemics. According to Kame'eleihiwa, 'by 1837 Christianity had so transformed the definition of pono that the $M^{-} \bar{c}^{\prime} \bar{i}$ and Ali' $i$ Nui were obliged to conform to the advice of their new kāhuna, regardless of their personal opinions'. ${ }^{2}$ While I agree with Kame'eleihiwa that ideas of and about pono were greatly affected by Christianity and other Western beliefs and practices, I assert that traditional understandings of pono were still at the foundation, and that Hawaiian understanding of the word pono was different from that of the haole ministers and businessmen.

Kamakau described his understanding of these differences in pono in his description of the lāhui:

Ua olelo nui ia ka lahui kanaka Hawaii, he lahui haipule i ke akua, he hookipa, he oluolu, he heahea, he aloha, he haawi wale i na mea ai a me na mea aahu, he kahea no i na malihini, e moe ma ka hale, e ai wale ana i ka ai a me ka ia, a e aahu wale ana no me ka uku ole. He lahui hilahila keia i ka piepiele. Oia ihola ke ano o keia lahui ma mua aku o ka hiki ana mai o na haole a me ka pono Kristiano ma Hawaii nei, a ke ao ia nei i ka aua ke pi, ka uahoa a me ke koea, a e ao i ka hauhauhali, a e puka i haoa a e hooio lea. Ua hooko no kekahi poe i keia, aka, o ka hapanui, he maumaua mai nei no na mamo a ka lokomaikai. O ka poe aua a pi hoi, ua hoohilahila loa ia ko lakou mau inoa. ${ }^{13}$

'It is commonly stated that the lāhui Hawai'i is a lāhui who praises God(s), who is welcoming, pleasant, calling out in greeting with aloha, who gives food and clothing freely, who calls out to strangers and visitors to sleep in their homes, to eat of their food and fish and clothe themselves, without any expectation of compensation. This is a lāhui that is ashamed of trading. That was the way of this lāhui before the arrival of the foreigners and the Christian morals here in Hawai'i, and it 
is only now that stinginess and greed are being learned, as well as treachery and taciturn behaviour, which breeds gossip and conspiracy, in seeking to make a profit, and conceitedly boast of it. Some people have mastered this, however, for the most part, the fruits of generosity continue on. And as for the stingy and greedy people, their names are shamed'.

Here, Kamakau described and defined the lāhui in terms of cultural practices; however, he also juxtaposed the lāhui Hawai' $i$ with the foreigners and their practices. These differences of cultural practice are represented as fundamental differences in world view about acceptable interaction, both personal and what the West calls business and trade. These differences become obvious in Kamakau's use of the word 'piepiele', and the description of Kānaka Maoli as 'he lahui hilahila i ka piepiele' ('a nation ashamed of piepiele'). The word 'piepiele' means to trade, a word and a concept that does not have negative connotations in English. In the Hawaiian system, however, it is a trade that is accompanied by bartering and bickering over the value of something, in order to gain the most profit. The overvaluing of one's own product or service while undervaluing another's for the purposes of personal gain was a reason for shame and embarrassment. It was recognized as taking advantage of another, and was, as such, not an action or attribute that was valued by Hawaiians. Kamakau explicitly states that this was the nature of the lāhui prior to the arrival of the 'haole' ('foreigners') and the 'pono Kristiano' (Christian forms of pono). Kamakau links the foreigners and Christian ideas of morality and proper behaviour together and positions them as directly opposite to Hawaiian ideas of morality and proper behaviour.

While every aspect of life in Hawai'i was greatly affected by the colonial influences of America and Europe, including the creation of a constitution and codified laws, pono continued to be a core value. According to Silva:

The constitution and laws in Hawai'i, while European in form, also reflected Kanaka Maoli ideas of what was pono in government. This is seen especially in the inclusion of women in government in the early years. Ali'i wahine (female ali'i) had always been part of government and for some years they continued to be. The office of kuhina nui was most often held by women, the first and most powerful of whom was Ka'ahumanu, who claimed status as coruler with Liholiho ... The first Hale 'Aha 'Ōlelo Ali'i, or House of Nobles (excluding the mōi 1 ), consisted of five women along with ten men. Ali'i 
wahine also served as island governors, among them Kuini Liliha on O'ahu, Kekauonohi on Kaua'i, and Ruth Ke'elikōlani on Hawai'i Island. ${ }^{14}$

The importance of pono in governance continued to be recognized and asserted by the descendants of Kamehameha. It was his son, Kauikeaouli, Kamehameha III, who asserted this upon his utterance of the phrase, 'Ua mau ke ea o ka 'āina i ka pono'. Kamehameha III made this statement upon the re-establishment of the Hawaiian Kingdom in July of 1843 , following the temporary cession of his sovereignty to Great Britain.

This phrase is usually translated as 'The life of the land is perpetuated in righteousness'. It is important, however, as previously discussed, to understand the multiple meanings and uses of words. In addition to meaning 'life,' 'ea' also means the 'breath', as well as 'sovereignty'. As such, the phrase must also be understood as meaning that, 'The sovereignty of the land continues in pono'. Silva has an excellent description of alternate meanings of this statement. In her description, she states:

'Ea', which can mean 'life' or 'breath' as well as 'sovereignty', in its original context was clearly meant to signify sovereignty. The word pono ... has a multiplicity of meanings, and had been appropriated by missionaries as well as government officials to translate the Christian concept of righteousness. In the mō'ís phrasing, it likely corresponds more closely to 'justice' and, more broadly, what is good or beneficial for the people. Simultaneously, it is an assertion that the mō's's government was the appropriate and correct one. ${ }^{15}$

Following the overthrow of the Hawaiian Kingdom in 1893 under Queen Lili'uokalani, assertions of pono continued to be central to conceptions of the nation and the kingdom, and as such are a central theme of the mele lāhui composed in response to the overthrow.

\section{E 'imi i ka pono o ka lāhui: The use of pono in mele lāhui}

Now let's look at the concepts of pono in mele lāhui. Let's start with the first mele lāhui published following the overthrow of the Hawaiian Kingdom government on January 17,1893 . A mere three days later, on January 20, 1893, this 
mele was printed on page two of the newspaper, Hawaii Holomua. The mele is entitled, 'Ka Pule a Ka Lahui Hawaii' ('The Prayer of the Hawaiian Lāhui') and is filled with requests to Iehova, the Christian God, to take away the suffering of the lāhui (line 8), to save Hawai'i (line 31), and also that Hawai'i will continue on and live on for the native born of Hawai'i (line 43-46)(Hawaii Holomua 1893). The word pono does not appear in the lines of the mele. Rather, one must look at a subtext in the mele, by reading the initial letter of each line from top to bottom.

\title{
KA PULE A KA LAHUI HAWAII
}

\author{
E-Iehova Sabaota \\ O-na kaua,--ke Kahikolu \\ $L$-aahia Hemolele, \\ $A$-lana ia no ko ke ao nei. \\ $O$-ka makou pule e maliu mai- \\ $K$-a puuhonua o makou nei, \\ $A$-lakai, hoopakele, nana mai, \\ $L$-awe aku i na popilikia \\ A-hoolilo i mea ole. \\ $N$-inini mai i Kou Hemolele, \\ I ola ai makou ma Ou 'la. \\ $L$-alau mai Kou aloha \\ I-hilinai manawalea, \\ $L$-aahia makamae \\ I-ko makou Lei Ali'aimoku. \\ $U$-hi Iaia me Kou mana, \\ $\mathrm{O}$-ka palekana a lanakila; \\ $N$-a kou nani e hoomohala, \\ $A$ - mao ae na pilihua. \\ $M$ - a Ou la-e ka Haku, \\ $O$-ko ke ao nei a pau, \\ $K$-a makou e pule nei, \\ $U$-hane Hemolele Kahikolu. \\ E-Iehova Sabaota, \\ $M$-akua o Aberahama me Davida. \\ $A$-lakai o ko ka Isaraela, \\ $U$-a ikea a hoonani ia. \\ $K$-e haliu aku nei makou, \\ $E$-waiho aku ma Kou mau wawae, \\ $E$-maliu mai i ka makou pule, \\ $A$-e hoopakele ia Hawaii. \\ $\mathrm{O}-\mathrm{Oe}$ hookahi e ka Haku, \\ $K$-o makou palekana,
}




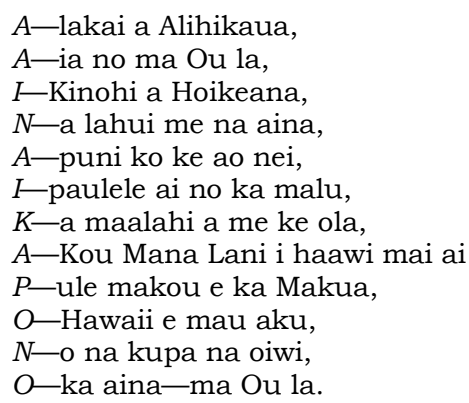

The unnamed composer of this mele has two other messages to convey to his audience in the acrostic subtext. The first verse requests, 'E ola o Kalani Liliu o na moku' ('Let the royal one, Lili'u, ruler of the islands live on'). This is not merely intended as a literal request for the Queen's life, but is also a prayer for her restoration to the throne, for the continuation of her life as the ruler of her people. The second verse requests, ' $\mathrm{E}$ mau ke ea o ka aina i ka pono'. This is based on Kamehameha III's statement 'Ua mau ke ea o ka 'āina i ka pono'. But here, the statement means that the life, the breath, the sovereignty of the land should continue on, it must continue on in a state of pono.

In addition to the hundreds of mele lāhui like the one above that were published in the Hawaiian language newspapers of the time, a collection of mele lāhui were also published in a book which was entitled, Buke Mele Lahui. It was published in 1895, following the kaua kūloko (civil war, counter-revolution) in which Hawaiian and other supporters of the Kingdom attempted to militarily restore control of the government to the Queen. As with other mele lāhui, ideas and expressions of pono were common in the mele found in the Buke Mele Lahui. Of the 105 mele found in the Buke Mele Lahui, thirty-five of them contain one or more references to pono.

Only one of the mele in the Buke Mele Lahui contains a line that very nearly duplicates Kamehameha III's statement with the same subtle difference seen in other mele. This mele states (in part ${ }^{16}$ ):

E mau ke Ea o Hawaii i ka Pono, The life, breath, sovereignty of Hawai'i must continue in pono, 
Many mele lāhui link government, ‘āina, and pono, demonstrating how vitally important these ideas were to the Hawaiian people's understanding of proper government. As you can see in these examples below, it was very important that the pono of the 'aina be 'imi' ('sought'), that it 'ho'i hou' ('return again'), and also that it should 'mau' ('continue on'). Here is one example of this:

Ua hui lokahi na puuwai,

E imi i ka pono o ka aina

The hearts have united as one, To seek the pono of the 'âina ${ }^{17}$

Many mele describe the important connection between the Mō'i (Queen) Lili'uokalani and her throne, her people, and her 'âina, as well as the importance of pono to each of these, as a symbol of the righteousness of her rule: 18

Aupuni Moi ku mau,

Hoohuiaina make loa, E ku e Kalani hanohano,

Paa i ka pono o ka lahui
The Monarchical Government will rule forever,

Annexation is truly dead, Let the glorious Royal One (the Queen) rule,

Secure in the pono of the nation

As in 'Ka Pule A Ka Lahui' above, many of the mele also connect the importance of religious practice and the recognition and blessings of the Gods, whether Hawaiian or Christian, as seen in these examples: ${ }^{19}$

Auhea kakou e ka lahui, E nonoi la i pono i ke Akua.

E pelu na kuli la i ka honua Haliu na maka i ke aouli,

O ka pono ia la o ka aina I welo hou ai Hae Kalaunu
Listen, people of the nation, We must request the pono from God.

Bend your knees to the earth Cast your eyes up to the heavens (and

It is the pono of the 'aina That the Crown Flag will wave again 
In some of the mele, the word pono is used in a manner that refers to the 'rights' of the Hawaiian people and its government. We see the word pono used in association with 'kiwwila' (or 'kivila'), which is the Hawaiianisation of the word 'civil', so that 'pono kiwila' is used to mean 'civil rights'. One of these references is found in the most popular of mele lāhui that continues to be sung and recorded until today. This mele is now commonly known as 'Kaulana Nā Pua', but was published under the name, 'Mele Aloha Aina', or 'Ai-pohaku':20

Hoohuiaina kuai hewa I ka pono kivila o ke kanaka
Annexation is a wrongful sale Of the pono kiwila of the people

In addition, we also see the word pono coupled with 'kaulike', which means 'equal', or on a similar level, and when coupled with pono, as in 'pono kaulike' is used to mean 'equal rights':21

E hana ana la i ka pono, Ka pono kaulike nou e Hawaii

They are working for the pono Pono kaulike for you, Hawai'i

\section{'O ka pono ka mea e pono ai: Conclusions on the importance of pono}

In examining these various meanings and uses of pono culturally, historically, and politically, it is clear that pono was an intrinsic part of the Hawaiian value system and instrumental in the formation of our identity and our nation. The mele lāhui act as a lens through which we can see the importance of pono in the world views of the Kānaka Maoli over 200 years following initial contact with the West and following the loss of Hawai'i's sovereignty and independence. The ideas and framings of pono are absolutely foundational to the very minds, hearts, and na'au (guts, intestines, place of carrying knowledge) of the Hawaiian people. These understandings of the importance of pono are still apparent in our conceptualisations of ourselves today and must continue to form the foundations of our identity. It is the choice, the prerogative, the right, and the responsibility of the Native 
Hawaiian people to define ourselves, and these traditional concepts and ideas of pono can and must provide the foundation of these definitions of ourselves, as well as our people, and our nation.

\section{Notes}

Although the text of this paper is in English, many of the sources are written in Hawaiian and one of the main goals of my research is a better understanding of Hawaiian ideas and concepts as expressed in Hawaiian.

2 M. K. Pukui, 'Ōlelo no'eau: Hawaiian proverbs and poetical sayings. Honolulu, 1983, p. 4.

3 M. K. Pukui, 'Ōlelo no'eau: Hawaiian proverbs and poetical sayings. Honolulu, 1983, p. 4.

4 M. K. Pukui, \& S. Elbert, Hawaiian Dictionary. Rev. ed. Honolulu, 1986, p. 340

5 L. Andrews, A Dictionary of the Hawaiian Language. Waipahu, Hawai'i: Island Heritage. Reprinted in 1974 Tokyo, 2003 [1865], p. 490.

$6 \quad$ S. M. Kamakau. 'Ka moolelo Hawaii.' Ke Au Okoa, 1869 (22 April), p. 1.

7 Translations have been provided by the author of this text unless otherwise noted.

Charlot, 1985, p. 2 .

Ibid., p. 1.

Ibid., p. 2 .

N. K. Silva, Aloha betrayed: Native Hawaiian resistance to American colonialism. Durham, NC, 2004, p. 16.

12 L. Kame'eleihiwa, Native Land and Foreign Desires, or Pehea lā e pono ai? Honolulu, 1992, p. 141

13 S. M. Kamakau, 'Ka moolelo o Kamehameha I', in $\mathrm{Ke} \mathrm{Au}$ Okoa (14 August) Edited and reprinted in Ke kumu aupuni. Honolulu: Ahahui 'Ōlelo Hawai'i, $1867,1996$.

$14 \quad$ N. K. Silva, p. 38.

15 Ibid., p. 37.

16 Kahelemauna, 'Mau Hawaii i ka lanakila.', in F. J. Testa. (ed) Buke mele lahui. 18. Honolulu 1895.

17 J. K. Kamali, 'Ke aloha i ka puuwai.', in F.J. Testa. (ed) Buke mele lahui. 15. Honolulu: 1895 .

18 B. Satana,. 'Ka wohi ku i ka moku', in F.J. Testa. (ed) Buke mele lahui, 37. Honolulu, 1895

19 W. Olepau, 'Liliu Lei a ka Lahui', in F.J. Testa. Buke mele lahui. 6. Honolulu, 1895.

20 Kekoaohiwaikalani, 'Mele aloha aina', in F.J. Testa. (ed) Buke mele lahui. 1. Honolulu, 1895, p. 1.

21 C. B. Kaila, 'E mau loa ke aloha.' , in F. J. Testa. (ed) Buke mele lahui. 18. Honolulu, p. 18. 